\title{
PENGARUH KOMPETENSI, MOTIVASI, DISIPLIN KERJA DAN KOMITMEN ORGANISASI TERHADAP KINERJA PEGAWAI PADA KANTOR PELAYANAN PAJAK PRATAMA TAPAK TUAN.
}

\author{
Yani Lapian Siregar \\ Universitas Islam Sumatera Utara \\ yani.lapian@gmail.com
}

\begin{abstract}
Problems in this research are: How does the influence of competence on the performance of employees of the Tread Tuan Tax Service Office, how does the influence of motivation on employee performance, how does the influence of work discipline on employee performance, how does the influence of organizational commitment on employee performance, how does the influence of competence, motivation, work discipline and organizational commitment to the performance of employees of the Tread Tuan Primary Tax Service Office.

The hypothesis proposed is: Competence has a positive and significant effect on the performance of the Tread Tuan Tax Office employee. Motivation has positive and significant effect on employee performance. Work discipline has positive and significant effect on employee performance. Organizational commitment has a positive and significant effect on employee performance, competence, motivation, work discipline and organizational commitment has positive and significant effect on employee performance. Sir". The research was conducted at the Pratama Tax Services Office of Jalan Tapen Tuan T.Ben Mahmud No. 26 Tapak Tuan-23718 Hilir Aceh Selatan with a research sample of 50 people. Based on the analysis results obtained Competency $-t$ Value $=$ 1,767, while $t$-table with dk 50 (Attachment) of 1,675 then t arithmetic $>t$-table thus partially there is a significant influence between Competency on employee performance. Value of $t$ Motivation = 3,213, while t-table with dk 50 (Attachment) is 1,675 then t arithmetic > t table thus partially there is a significant influence between motivation on employee performance. The value of $t$ work discipline $=4.040$ while the $t$-table with $d k 50$ (Appendix) of 1.675 then tarithmetic $>t$ table thus partially there is a significant influence between work discipline on employee performance. The value of t organizational commitment $=4.631$ while the $t$-table with $d k 50$ (Appendix) of 1.675 then $t$ arithmetic $>t$ table thus partially there is a significant influence between organizational commitment to employee performance. The F-count value is 367,036 while the F-table value (Appendix) with the numerator $d k 4$ and the denominator $d k 45$ is 2.57 where the $F$-count $>F$ table (359,434> 2.57) then it can be mentioned that together ( multiple) there is a positive and significant influence Competency, discipline motivation and organizational commitment, on employee performance. Thus the hypothesis 5 submitted accepted the truth.
\end{abstract}

Keyword: Competence, Motivation, Discipline, Organizational Commitment and Employee Performance

ABSTRAK : Masalah dalam peneltian ini adalah:Bagaimana pengaruh kompetensi terhadap kinerja pegawai Kantor Pelayanan Pajak Pratama Tapak Tuan, bagaimana pengaruh motivasi terhadap kinerja pegawai, bagaimana pengaruh disiplin kerja terhadap kinerja pegawai,bagaimana pengaruh komitmen organisasi terhadap kinerja pegawai,bagaimana pengaruh kompetensi, motivasi, disiplin kerja dan komitmen organisasi terhadap kinerja pegawai Kantor Pelayanan Pajak Pratama Tapak Tuan. Hipotesis yang diajukan adalah :Kompetensi berpengaruh positif dan signifikan terhadap kinerja pegawai Kantor Pelayanan Pajak Pratama Tapak Tuan. Motivasi berpengaruh positif dan signifikan terhadap kinerja pegawai, Disiplin kerja berpengaruh positif dan signifikan terhadap kinerja pegawai, Komitmen organisasi berpengaruh positif dan signifikan terhadap kinerja pegawai, Kompetensi, motivasi, disiplin kerja dan komitmen organisasi berpengaruh positif dan signifikan terhadap kinerja pegawai Kantor Pelayanan Pajak Pratama Tapak Tuan".Penelitian dilakukan di Kantor Pelayanan Pajak Pratama Tapak Tuan 
Jalan T.Ben Mahmud No. 26 Tapak Tuan-23718 Hilir Aceh Selatan dengan sampel penelitian sebanyak 50 orang. Berdasarkan hasil analisis diperoleh Nilai $-t$ Kompetensi $=1,767$, sedangkan t- tabel dengan dk 50 (Lampiran) sebesar 1,675 maka thitung $>t$-tabel dengan demikian secara parsial ada pengaruh yang signifikan antara Kompetensi terhadap kinerja pegawai pegawai.Nilai $t$ Motivasi $=3,213$, sedangkan $t$-tabel dengan $d k 50$ (Lampiran) sebesar 1,675 maka $t$ hitung $>t$ tabel dengan demikian secara parsial ada pengaruh yang signifikan antara Motivasi terhadap kinerja pegawai.Nilai $t$ disiplin kerja $=4,040$ sedangkan $t$-tabel dengan $d k 50$ (Lampiran) sebesar 1,675 maka t hitung > t tabel dengan demikian secara parsial ada pengaruh yang signifikan antara disiplin kerja terhadap kinerja pegawai. Nilai $t$ komitmen organisasi $=4,631$ sedangkan t-tabel dengan $d k 50$ (Lampiran) sebesar 1,675 maka thitung > t tabel dengan demikian secara parsial ada pengaruh yang signifikan antara komitmen organisasi terhadap kinerja pegawai. Nilai $F$ hitung sebesar 367,036sedangkan nilai F-tabel (Lampiran) dengan dk pembilang 4 dan $d k$ penyebut 45 adalah sebesar 2,57 dimana F-hitung > $F$ tabel $(359,434>2,57)$ maka dapat disebutkan bahwa secara bersama-sama (multiple) terdapat pengaruh positif dan signifikan Kompetensi, Motivasi disiplin dan komitmen organisasi, terhadap kinerjaPegawai. Dengan demikian hipotesis 5 yang diajukan diterima kebenarannya.

Keyword : Kompetensi, Motivasi, Disiplin, komitmen organisasi dan Kinerja Pegawai

\section{Pendahuluan}

Kunci sukses pertumbuhan setiap organisasi adalah kemampuannya dalam merekrut, mengembangkan dan mempertahankan talenta sumber daya manusianya. Kantor Pelayanan Pajak Pratama Tapak Tuan telah menetapkan sasarannya untuk menjadi organisasi pilihan untuk berkarya dengan menjadi organisasi yang menawarkan lingkungan kerja positif di mana setiap individu dapat mengembangkan seluruh potensinya. Kantor Pelayanan Pajak Pratama Tapak Tuan melaksanakan struktur organisasi yang memungkinkan sumber daya manusia berkualitas dan kompetitif sehingga mampu beradaptasi dengan kemajuan dan perkembangan ilmu dan teknologi untuk menghasilkan kerja yang baik dan pelayanan terbaik sesuai dengan yang diharapkan.

Kantor Pelayanan Pajak Pratama Tapak Tuan dalam mencapai tujuannya tidak terlepas dari kinerja pegawai yang ada dalam organisasi tersebut. Pegawai memainkan peranan yang sangat penting dalam mencapai keberhasilan dinas. Seberapa baik seorang pemimpin mengelola kinerja bawahannya akan secara langsung mempengaruhi kinerja individu, unit kerja dan organisasi secara keseluruhan.

Penilaian kinerja pada dasarnya merupakan salah satu faktor kunci guna mengembangkan suatu organisasi secara efektif dan efisien, karena adanya kebijakan atau program penilaian prestasi kerja, berarti organisasi telah memanfaatkan secara baik atas sumber daya manusia yang ada dalam organisasi. Permasalahan yang biasa muncul dalam proses penilaian adalah terletak pada bagaimana objektivitas penilaian dapat dipertahankan. Dengan kemampuan mempertahankan objektivitas penilaian, maka hasil penilaian menjadi terjaga akurasi dan validitasnya. Untuk menjaga sistem penilaian yang objektif hendaknya para penilai, harus menghindarkan diri dari adanya faktor suka dan tidak suka. Dengan penilaian yang objektif diharapkan dapat meningkatkan kinerja pegawai. Permasalahan tentang kinerja pegawai Kantor Pelayanan Pajak Pratama Tapak Tuan saat ini terletak pada target penerimaan pajak yang belum tercapai sesuai yang ditargetkan, sehingga hal ini menjadi dasar peneliti dalam melakukan penelitian ini.

Berdasarkan survei awal, faktor yang mempengaruhi kinerja pegawai Kantor Pelayanan Pajak Pratama Tapak Tuan adalah komitmen organisasi. Penelitian terdahulu dari Sri Yani (2005), menjelaskan bahwa kompetensi manajerial dan komitmen organisasi berpengaruh positif terhadap kinerja. Sekarang ini komitmen organisasi dapat dijadikan landasan daya saing, karena organisasi atau instansi dengan pegawai yang mempunyai komitmen akan mendapatkan keunggulan-keunggulan yang tidak dimiliki oleh organisasi atau instansi lain seperti adanya kepercayaan yang kuat untuk menerima tujuan dan nilai-nilai organisasi, kesediaan untuk melakukan usaha yang diatasnamakan organisasi, serta adanya keinginan yang kuat untuk mempertahankan keanggotaannya di dalam organisasi tersebut.

Faktor lain yang mempengaruhi kinerja pegawai Kantor Pelayanan Pajak Pratama 
Tapak Tuan adalah kompetensi. Kompetensi pegawai dapat juga digunakan sebagai daya saing (competitive advantages) organisasi atau instansi. Sri Yani (2005), menjelaskan bahwa kompetensi manajerial dan komitmen organisasi berpengaruh positif terhadap kinerja. Pengembangan dan penciptaan daya saing dalam jangka panjang hanya dapat diperoleh dari usaha menananamkan dan membangun kompetensi, melakukan inovasi terus menerus dan bergerak lebih cepat dari para pesaing, Suhartono (2015:66), menyatakan kompetensi itu merujuk kepada karakteristik yang mendasari perilaku yang menggambarkan motif, karakteristik pribadi (ciri khas), konsep diri, nilai-nilai, pengetahuan atau keahlian yang dibawa seseorang yang berkinerja unggul di dalam suatu organisasi.

Menurut Golemen (2015:213) ada 5 karakteristik dari kompetensi yaitu skills (kemampuan), knowledge (pengetahuan), self concepts (attitude, value, self image), traits dan motives. Tingginya kompetensi yang dimiliki oleh pegawai akan mewujudkan kinerja yang unggul, karena kompetensi berperan sebagai input, produksi dan proses dalam suatu pekerjaan. Sebagai input, kompetensi adalah kapasitas atau potensi yang muncul dalam diri seseorang untuk menyelesaikan suatu masalah dengan baik. Kapasitas disini terdiri dari pengetahuan, keterampilan dan perilaku. Input kompetensi dapat menggunakan dua bentuk, yaitu kemampuan yang diperoleh dari belajar, latihan atau pengalaman, dan kemampuan yang diperoleh dalam diri individu yang mempengaruhinya dengan kuat. Sementara itu, kompetensi sebagai proses adalah merangkai input dan produksi. Inputnya adalah pengetahuan dan keterampilan, sedangkan produksinya adalah pencapaian hasil yang diinginkan dan proses penggunaan pengetahuan serta keterampilan untuk mencapai tujuan yang dimaksud. Dengan demikian, sangat jelas bahwa kompetensi itu merupakan faktor yang sangat penting dalam upaya menghasilkan kinerja yang optimal

Selanjutnya kinerja pegawai Kantor Pelayanan Pajak Pratama Tapak Tuan dapat juga dipengaruhi oleh faktor internal maupun faktor eksternal seperti motivasi. Hal ini sejalan dengan pendapat Kleiman (2012:166) menyatakan bahwa motivasi adalah kesediaan pegawai untuk mengeluarkan tingkat upaya yang tinggi untuk tujuan organisasi yang dikondisikan oleh kemampuan upaya itu dalam memenuhi beberapa kebutuhan individual. Kebutuhan terjadi apabila tidak ada keseimbangan antara apa yang dimiliki dan apa yang diharapkan. Dorongan merupakan kekuatan mental yang berorientasi pada pemenuhan harapan dan pencapaian tujuan, sedangkan tujuannya merupakan sasaran atau hal yang ingin dicapai oleh seorang pegawai. Teori Herzberg tentang motivasi berpendapat bahwa ada dua faktor tentang motivasi yaitu faktor ekstrinsik dan instrinsik. Faktor ekstrinsik adalah hubungan interpersonal antara atasan dengan bawahan, teknik supervisi, kebijakan administratif, kondisi kerja dan kehidupan pribadi. Sedangkan faktor intrinsik adalah faktor yang kehadirannya dapat menimbulkan kinerja pegawai yang berasal dari dalam diri pegawai.

Untuk menciptakan kondisi tersebut, terlebih dahulu harus di wujudkan keselarasan antara hak dna kewajiban pegawai. Walaupun disadari oleh banyak pihak bahwa motivasi, komitmen organisasi dan kompetensi serta disiplin pegawai merupakan faktor penting dalam meningkatkan kinerja pegawai, namun dalam prakteknya belum semua organisasi mampu mewujudkannya. Fenomena yang terjadi di Kantor Pelayanan Pajak Pratama Tapak Tuan terkait pada kinerja pegawai antara lain tingkat pelayanan ke wajib pajak belum optimal dan masih ada terjadi gangguan jaringan IT.

Berdasarkan uraian di atas, banyak faktor yang berpengaruh pada variabel kinerja pegawai Kantor Pelayanan Pajak Pratama Tapak Tuan, sehingga dalam penelitian ini peneliti membatasi kepada variabel independen yaitu kompetensi, motivasi, disiplin kerja dan komitmen organisasi diduga berpengaruh terhadap kinerja pegawai.

a. Untuk mengetahui dan menganalisis pengaruh kompetensi terhadap kinerja pegawai Kantor Pelayanan Pajak Pratama Tapak Tuan.

b. Untuk mengetahui dan menganalisis pengaruh motivasi terhadap kinerja pegawai Kantor Pelayanan Pajak Pratama Tapak Tuan..

c. Untuk mengetahui dan menganalisis pengaruh disiplin kerja terhadap kinerja pegawai Kantor Pelayanan Pajak Pratama Tapak Tuan.

d. Untuk mengetahui dan menganalisis pengaruh komitmen organisasi terhadap kinerja pegawai Kantor Pelayanan Pajak Pratama Tapak Tuan. 
e. Untuk mengetahui dan menganalisis pengaruh kompetensi, motivasi, disiplin kerja dan komitmen organisasi terhadap kinerja pegawai Kantor Pelayanan Pajak Pratama Tapak Tuan.

\section{Metode Penelitian}

\subsection{Lokasi Penelitian}

Penelitian ini dilakukan di Kantor PelayananPajakPratamaTapak Tuan Jalan T.Ben Mahmud No. 26 Tapak Tuan-23718 Hilir Aceh Selatan

\subsection{Populasi}

Menurut Sugiyono (2004:90) populasi adalah wilayah generasi yang terdiri dari atas objek/subjek yang mempunyai kualitas karakteristik tertentu yang disajikan oleh peneliti untuk dipelajari dan kemudian ditarik kesimpulannya. Berdasarkan defenisi tersebut, maka populasi dalam penelitian ini adalah para pegawai Kantor Pelayanan Pajak Pratama Tapak Tuan yang berjumlah 67 orang, dimana peneliti tidak dimasukkan sebagai sampel denganrincian sebagai berikut :

Tabel 1

Distribusi populasi penelitian berdasarkan jabatan

\begin{tabular}{|c|l|c|}
\hline No & \multicolumn{1}{|c|}{ Keterangan/Jabatan } & $\begin{array}{c}\text { Jumlah } \\
\text { (Orang) }\end{array}$ \\
\hline 1 & Kepala Kantor & 1 \\
\hline 2 & KepalaSeksi & 8 \\
\hline 3 & Account Representative & 12 \\
\hline 4 & Fungsional & 9 \\
\hline 5 & Pelaksana & 37 \\
\hline \multicolumn{2}{|c|}{ Total } & 67 \\
\hline
\end{tabular}

Sumber :Kantor PelayananPajakPratamaTapak Tuan2019

\section{Sampel}

Untuk menentukan jumlah sampel, digunakan pendapat Slovin dalam Sekaran dan Bougie (2010:112) dengan menggunakan formula sebagai berikut :

Keterangan :

$$
n=\frac{N}{1+N \mathrm{e}^{2}}
$$

$\mathrm{n}$ : JumlahSampel

$\mathrm{N}$ : JumlahPopulasi

$$
e: \quad \text { Kesalahan }
$$

ditolerirdalampenarikansampelyaitu 0,05 .

yang

Berdasarkan formula diatas, selanjutnya dapat dihitung jumlah sampel dalam penelitianini sebagai berikut :

$$
\begin{aligned}
& \mathrm{n}=\frac{66}{1+66(0,05)^{2}} \\
& \mathrm{n}=\frac{66}{1.32} \\
& \mathrm{n}=50=50 \text { orang }
\end{aligned}
$$

Setelah perhitungan di atas, penetapan jumlah sampel dalam penelitian ini menggunakan metode stratified random sampling yaitu penarikan sampel berdasarkan pada strata populasi pada setiap bagian, sehingga sampel dalam penelitian ini berjumlah 50 orang pegawai, dengan rincian sebagai berikut :

Tabel 2

Distribusi sampel penelitian berdasarkan jabatan

\begin{tabular}{|l|l|c|}
\hline No & \multicolumn{1}{|c|}{ Keterangan/Jabatan } & $\begin{array}{c}\text { Jumlah } \\
\text { (Orang) }\end{array}$ \\
\hline 1 & KepalaSeksi & 8 \\
\hline 2 & Account Representative (AR) & 12 \\
\hline 3 & Fungsional & 9 \\
\hline 4 & Pelaksana & 21 \\
\hline \multicolumn{2}{|c|}{ Jumlah } & 50 \\
\hline \multicolumn{2}{|l|}{} \\
2019
\end{tabular}

\subsection{Teknik Pengumpulan Data}

Teknik pengumpulan data yang tepat, dengan mempertimbangkan penggunaannya berdasarkan jenis data dan sumbernya.Data yang obyektif dan relevan dengan pokok permasalahan penelitian merupakan indikator keberhasilan suatu penelitian.Pengumpulan data penelitian dilakukan dengan cara pengisian kuisioner dan wawancara untuk memperoleh data primer, sesuai dengan tujuan penelitian. Peneliti menemui responden secara langsung, tentunya sesuai dengan peraturan dan tidak mengganggu kelangsungan proses kerja di Kantor Pelayanan Pajak Pratama Binjai.

\section{Kuesioner (Angket)}

Kuesioner merupakan teknik pengumpulan data yang dilakukan dengan cara memberi seperangkat pertanyaan atau pernyataan tertulis kepada responden untuk dijawabnya.

\section{Studi Pustaka}

Metode pencarian informasi dari buku-buku yang relevan dan sumber yang lain yang membahas masalah dalam penelitian ini.

\section{Studi Dokumentasi}

Studi dokumentasi merupakan cara untuk mencari informasi tentang data pegawai atau hal-hal lain yang terkait pada variabel yang 
diteliti dari Kantor Pelayanan Pajak Pratama Binjai, seperti data pegawai, struktur organisasi, tupoksi dan lain sebagainya.

\subsection{Teknik Analisa Data}

Teknik analisis data menggunakan validitas dan realibilitas, uji asumsi klasik dengan menggunakan uji Multikolinearitas, Multikolinearitas, Uji Heteroskedastisitas. Pengujian Hipotesis menggunakan uji regresi berganda.

\section{Tabel 3}

\section{Analisis dan Pembahasan}

\subsection{Analisis Regresi}

Analisis regresi digunakan untuk menganalisis data hasil penelitian dengan maksud untuk memperoleh gambaran hubungan fungsional antara antara variabel bebas dengan variabel terikat hal ini dengan menggunakan analisis regresi linier berganda

Berdasarkan analisis regresi linier ganda (Multiple) sebagaimana pada lampiran 10 diperoleh koefisien regresi sebagai berikut.

Koefisien Regresi

\begin{tabular}{|c|c|c|c|c|c|}
\hline \multirow[t]{2}{*}{ Model } & \multicolumn{2}{|c|}{$\begin{array}{l}\text { Unstandardized } \\
\text { Coefficients }\end{array}$} & \multirow{2}{*}{$\begin{array}{l}\text { Standardized } \\
\text { Coefficients } \\
\text { Beta }\end{array}$} & \multirow[t]{2}{*}{$\mathrm{t}$} & \multirow[t]{2}{*}{ Sig. } \\
\hline & $\mathrm{B}$ & \begin{tabular}{|l} 
Std. \\
Error
\end{tabular} & & & \\
\hline (Constant) & 3.742 & .864 & & 4.329 & .000 \\
\hline Kompetensi & .059 & .043 & .066 & 1.767 & .179 \\
\hline Motivasi & .233 & .073 & .228 & 3.213 & .002 \\
\hline Disiplin kerja & .380 & .094 & .373 & 4.040 & .000 \\
\hline Komitmen organisasi & .396 & .085 & .353 & 4.631 & .000 \\
\hline
\end{tabular}

Berdasarkan Tabel 5.20diperoleh koefisien regresi variabel kompetensi 0,059, Motivasi = 0,233, disiplin kerja, 0,380 dan komitmen organisasi 0,396 dengan konstanta 5,695, maka dapat dituliskan persamaan regresi sebagai berikut.

$$
\begin{gathered}
Y=3,742+0,059 X_{1}+0,233 X_{2}+0,380 X_{3}+ \\
0,396 X_{4}
\end{gathered}
$$

Persamaan di atas menunjukkan konstanta bernilai positip dan nilai koefisien regresi juga positip. Hal ini memberi gambaran bahwa perubahan rata-rata variabel kinerja pegawai Pegawai (Y) tergantung dari perubahan variabel Kompetensi $\left(\mathrm{X}_{1}\right)$, Motivasi $\left(\mathrm{X}_{2}\right)$. Disiplin $\left(\mathrm{X}_{3}\right)$ dan komitmen organisasi $\left(\mathrm{X}_{4}\right)$ Artinya apabila Kompetensi, Motivasi, disiplin dan kompetensi organisasiditingkatkan akan diikuti perubahan kinerjapegawai. Perubahan ini merupakan peningkatan apabila bertanda positip dan penurunan atau pengurangan jika bertanda negatif. Hal ini menunjukkan bahwa ada pengaruh kompetensi, Motivasi, disiplin, dan kompetensi organisasiterhadap kinerja pegawai pegawai.

\subsection{Uji Hipotesis}

\subsubsection{Uji - t (Parsial)}

Untuk mengetahui pengaruh variabel bebas secara parsial terhadap variabel terikat digunakan uji t, dimana dengan ketentuan :

t- hitung $\leq \mathrm{t}$ - tabel ...............tidak ada pengaruh variabel bebas secara tersendiri terhadap variabel terikat

t- hitung > t- tabel ............... tidak ada pengaruh variabel bebas secara tersendiri terhadap variabel terikat

derajat kebebasan $(\mathrm{dk})=\mathrm{n}-2$ dan Tingkat kepercayaan $\alpha=0,05$,

Berdasarkan hasil analisis pada lampiran 10sebagaimana dalam tabel 5.20 di atas diperoleh nilai $-\mathrm{t}$ Kompetensi $=1,767$, sedangkan t-tabel dengan $\mathrm{dk} 50$ (Lampiran) sebesar 1,675 maka thitung > t-tabel dengan demikian secara parsial ada pengaruh yang signifikan antara Kompetensi terhadap kinerja pegawai pegawai.

Selanjutnya nilai $\mathrm{t}$ Motivasi $=3,213$, sedangkan t-tabel dengan $\mathrm{dk} 50$ (Lampiran) sebesar 1,675 maka t hitung > t tabel dengan demikian secara parsial ada pengaruh yang signifikan antara Motivasi terhadap kinerja pegawai. 
Nilai $\mathrm{t}$ disiplin kerja $=4,040$ sedangkan $\mathrm{t}$ tabel dengan dk 50 (Lampiran) sebesar 1,675 maka $\mathrm{t}$ hitung $>\mathrm{t}$ tabel dengan demikian secara parsial ada pengaruh yang signifikan antara disiplin kerja terhadap kinerja pegawai.

Nilai $t$ komitmen organisasi $=4,631$ sedangkan t-tabel dengan $\mathrm{dk} 50$ (Lampiran) sebesar 1,675 maka $t$ hitung $>\mathrm{t}$ tabel dengan demikian secara parsial ada pengaruh yang signifikan antara komitmen organisasi terhadap kinerja pegawai.

Untuk mengetahui pengaruh variabel bebas secara bersama-sama terhadap variabel terikat digunakan uji-F, (Sudjana, 2013:355) dengan rumus:

$$
: F_{h i t}=\frac{J K_{r e g} / k}{J K_{r e s} /(n-k-1)}
$$

Tabel 4

Uji F (Simultan)

ANOVA

\begin{tabular}{|rl|r|r|r|l|l|}
\hline Model & \multicolumn{1}{|l|}{$\begin{array}{l}\text { Sum of } \\
\text { Squares }\end{array}$} & df & Mean Square & F & Sig. \\
\hline \multirow{4}{*}{1} & Regression & 803.298 & 4 & 200.825 & 367.036 & $.000^{\text {b }}$ \\
& Residual & 24.622 & 45 & .547 & & \\
& Total & 827.920 & 49 & & & \\
\hline
\end{tabular}

a. Dependent Variable: Kinerja pegawai

b. Predictors: (Constant), Komitmen organisasi, Kompetensi, Motivasi, Disiplin kerja

Berdasarkan tabel di atas diketahui nilai Fhitung sebesar 367,036sedangkan nilai F-tabel (Lampiran) dengan $\mathrm{dk}$ pembilang $4 \mathrm{dan} \mathrm{dk}$ penyebut 45 adalah sebesar 2,57 dimana Fhitung > F tabel $(359,434>2,57)$ maka dapat disebutkan bahwa secara bersama-sama (multiple) terdapat pengaruh positif dan signifikan Kompetensi, Motivasi disiplin dan komitmen organisasi, terhadap kinerjaPegawai. Dengan demikian hipotesis 5 yang diajukan diterima kebenarannya.

\subsection{Uji Determinasi}

Berdasarkan hasil analisis data kompetensi Pegawai di Kantor Pelayanan Pajak Pratama Tapak Tuan umumnya sangat banyak, Motivasi pegawai rendah, pegawai tidak disiplin,dan komitmen organisasi rendah, dan kinerja pegawai pegawai kurang tinggi.Kinerja
Dimana :

$\mathrm{JK}_{\text {reg }}=$ Jumlah kuadrat regresi

$\mathrm{JK}_{\mathrm{reg}}=$ Jumlah kuadrat residu

$\mathrm{n}=$ Jumlah Sampel

$\mathrm{K}=$ Jumlah varians

Jika : $\mathrm{F}$ hitung > F tabel : Hipotesis alternatip diterima

$\mathrm{F}$ hitung < F tabel : Hipotesis

alternatip ditolak (Ho diterima)

Penelitian ini menggunakan tingkat

kepercayaan $95 \%(\alpha=0.05)$

\subsubsection{Uji - F (Simultan)}

Berdasarkan analisis varians (Anova) pada tabel 4, dengan hasil sebagai berikut. pegawai dapat meningkat apabilakompetensi ditingkatkan,Motivasi semakin baikdisiplin kerja ditingkatkankomitmen organisasi ditingkatkan dan kinerja juga ditingkatkan, karena hasil analisis regresi dan pengujian hipotesis diperoleh terdapat pengaruh signifikan Kompetensi, Motivasi, disiplin kerja dan komitmen organisasiterhadap kinerja pegawai pegawai. Apabila Kompetensi ditingkatkan, Motivasi semakin tinggi,disiplin semakin ditingkatkan dan komitmen organisasi ditingkatkan $1 \%$ maka dkinerja pegawai Pegawai akan naik menjadi 1\%. Besarnya pengaruh kompetensi, motivasi, disiplin kerjadan komitmen organisasi terhadap kinerja pegawai Pegawai dapat diketahui melalui uji determinasi (D) dimana $D=R^{2} \times 100 \%$. Hasil analisis pada model summary sebagaimana pada lampiran 10 sebagai berikut.

\section{Tabel 5}

Model Summary

\begin{tabular}{|l|l|l|l|ll|}
\hline Model & R & R Square & Adjusted R Square & \multicolumn{2}{|l|}{$\begin{array}{l}\text { Std. Error of the } \\
\text { Estimate }\end{array}$} \\
\hline 1 & $.985^{\mathrm{a}}$ & .970 & .968 & .73970 \\
\hline
\end{tabular}

Sumber : Hasil SPSS, 2019 
Berdasarkan tabel 5.22diperoleh $\mathrm{R}^{2}=0,970$ maka $\mathrm{D}=0,970 \mathrm{x} 100 \%$ sehingga $\mathrm{D}=97 \%$. Dengan demikian pengaruh Kompetensi, Iklim Kerja,disiplin dan motivasiterhadap kinerja pegawai pegawai sebesar 97\%. sedangkan 3\% lagi yang mempengaruhi peningkatan kinerjaPegawai ditentukan faktor lain yang tidak diteliti dalam penelitian ini..

\section{Kesimpulan}

Sesuai hasil analisis penelitian maka dapat diamil kesimpulan sesuai tujuan penelitian yang dikemukakan.

a. Nilai -t Kompetensi $=1,767$, sedangkan $\mathrm{t}$ tabel dengan dk 50 (Lampiran) sebesar 1,675 maka $t$ hitung $>$ t-tabel dengan demikian secara parsial ada pengaruh yang signifikan antara Kompetensi terhadap kinerja pegawai pegawai.

b. Nilai t Motivasi $=3,213$, sedangkan t-tabel dengan $\mathrm{dk} 50$ (Lampiran) sebesar 1,675 maka $\mathrm{t}$ hitung $>\mathrm{t}$ tabel dengan demikian secara parsial ada pengaruh yang signifikan antara Motivasi terhadap kinerja pegawai.

c. Nilai $\mathrm{t}$ disiplin kerja $=4,040$ sedangkan $\mathrm{t}$ tabel dengan $\mathrm{dk} 50$ (Lampiran) sebesar 1,675 maka $\mathrm{t}$ hitung $>\mathrm{t}$ tabel dengan demikian secara parsial ada pengaruh yang signifikan antara disiplin kerja terhadap kinerja pegawai.

d. Nilai $\mathrm{t}$ komitmen organisasi $=4,631$ sedangkan t-tabel dengan dk 50 (Lampiran) sebesar 1,675 maka t hitung > t tabel dengan demikian secara parsial ada pengaruh yang signifikan antara komitmen organisasi terhadap kinerja pegawai.

e. Nilai F-hitung sebesar 367,036sedangkan nilai F-tabel (Lampiran) dengan $\mathrm{dk}$ pembilang 4 dan $\mathrm{dk}$ penyebut 45 adalah sebesar 2,57 dimana F-hitung > F tabel $(359,434>2,57)$ maka dapat disebutkan bahwa secara bersama-sama (multiple) terdapat pengaruh positif dan signifikan Kompetensi, Motivasi disiplin dan komitmen organisasi, terhadap kinerjaPegawai. Dengan demikian hipotesis 5 yang diajukan diterima kebenarannya.

\section{DAFTAR PUSTAKA}

Apollo Daito, 2011, Metodologi Penelitian Skripsi/Tesis/Disertasi, Universitas Budi Luhur

Colquitt, LePine, Wesson, 2009, Organizational Behavior Improving Performance and
Commitment in The Workplace, Mc Graw Hill International Edition

Cooper,Donald, Pamela S Schindler,2009, Business Research Methods, New York: McGraw Hill, Inc

Fisher, Martin, 2015, Performance Appraisals, Kogan Page Limited

Goleman, Daniel, 2015, Emotional Intelligence, Cetakan keenambelas, terjemahan, Gramedia

Kleiman, Lawrence S, 2012, Human Resource Management : A Tool For Competitive Advantage, West Publishing Company

Mathis, Robert L and Jackson, John H, 2010, Manajemen Sumber Daya Manusia, Edisi 10, terjemahan, Salemba Empat

Milkovich, T George and Newman, Jerry M, 2010, Competency, Mc Graw Hill International Edition

Murphy, Kevin R and Cleveland, Jeanette N, 2010, Performance Appraisal : An Organizational Perspective,Colorado State University

R Palan, 2010, Competency Manajemen : Teknik Mengimplementasikan Manajemen SDM Berbasis Kompetensi untuk Meningkatkan Daya Saing Organisasi, Seri Manajemen Sumber daya Manusia No.13

Rivai Veithzal, 2012, Manajemen Sumber Daya Manusia untuk Perusahaan dari Teori ke Praktik, RajaGrafindo Persada, Jakarta

Robbins P. Stephen, Coulter Mary alih bahasa oleh Benyamin, (2010), Manajemen, Edisi keenam, Jilid 2, PT. Indeks Jakarta

Rush, Michael dan Althoff, Phillip,2010. Pengantar Sosiologi Politik. Jakarta: PT. Raja Grafindo Persada

Sedarmayanti. (2009). Good Governance (Kepemerintahan Yang Baik), Bandung : Mandar Maju

Siagian P. Sondang, 2012, Organisasi Kepemimpinan dan Prilaku Organisasi, Gunung Agung Jakarta

Simamora, H. 2014. Manajemen Sumber Daya Manusia. Edisi Ketiga. Yogyakarta: Sekolah Tinggi Ilmu Ekonomi YKPN

Sekaran Umar, 2011, Research Methods For Business, University at Corbandale

Sugiyono. 2014. Metode Penelitian Bisnis. Alfabeta Bandung

Triton PB (2015), Paradigma Baru Manajemen Sumber Daya Manusia, Tugu Yogyakarta. (2016), SPSS 12.00 Terapan Riset Statistik Parametrik, Andi Yogyakarta. 
Wahjosumidjo, 2015, Kepemimpinan dan Motivasi, Liberty Yogyakarta

Wibowo, 2013. Manajemen Kinerja. Cetakan Pertama. Jakarta: Raja Grafindo Persada

\section{ARTIKEL, JURNAL, TESIS}

Budi Setiawan, Proses Transformasi Kompetensi Pegawai Menjadi Modal Maya Organisasional yang Efektif, Wacana Kerja Vol. 6 Nomor 3, September 2003 : 25-54

Guntur Ujianto dan Syafarudin Alwi, Analisis Pengaruh Komitmen Profesional dan Komitmen Organisasional Terhadap Kepuasan Kerja Karyawan Pada Bank Bukopin Yogyakarta, Sinergi Kajian Bisnis dan Manajemen 2005 halaman 93-110

H.M. Moerad Baso 2003, Pembinaan SDM Berbasis Kompetensi : Suatu Pendekatan Strategik Dalam Upaya Peningkatan Kualitas SDM dalm Konteks Globalisasi dan Otonomi Daerah, Majalah Usahawan No. 02 TH XXXII, Februari 2003 halaman 35-41

H. Teman Koesmono, Pengaruh Kepribadian Terhadap Komitmen Organisasi dan Perilaku serta Kinerja Karyawan Pada Perusahaan Perkayuan di Jawa Timur, Jurnal Widya Manajemen dan Akuntansi, Vol. 4 No. 3 Desember 2004 halaman 235-247

Huntal Parulian Simanjuntak 2004, Hubungan Antara Iklim Komunikasi Organisasi dan Kompetensi Dengan Kinerja Karyawan PT. Jasa Raharja (Persero), Tesis, Universitas Indonesia, Jakarta

I Made Wijaya 2006, Analisis Pengaruh Kecerdasan Emosional dan Komitmen Organisasi Terhadap Kinerja Pelayanan Pegawai Pada Kantor Pelayanan Tipe A
Tanjung Priok III, Direktorat Jenderal Bea dan Cukai (DJBC), Departemen Keuangan Republik Indonesia, Tesis, Universitas Indonesia, Jakarta

Oktavianus Pasoloran, Pengaruh Locus of Control Terhadap Hubungan Antara Kepuasan Kerja Dan Komitmen Organisasi, SIMAK Volume 1,Nomor 1, Oktober 2003 halaman 13-33

Sri Haryani, Komitmen Karyawan Sebagai Keunggulan Bersaing,Telaah Bisnis Volume 2, Nomor 2, Desember 2008 halaman 151160

Sri Yani 2005, Hubungan Antara Kompetensi Manajerial dan Komitmen Organisasi Dengan Kinerja Pejabat Struktural Eselon III-IV Pada Sekretariat Jenderal Dewan Perwakilan Rakyat Republik Indonesia, Tesis, Universitas Indonesia, Jakarta

Suhartono, Pengaruh Kompetensi Bidang Fungsional Berdasarkan Faktor Keunggulan Bersaing Terhadap Kinerja Perbankan di Indonesia, Majalah Manajemen, Akuntansi dan Bisnis Volume 3, Nomor 2, Agustus 2005, halaman 157-175

Torang Sitanggang 2005, Pengaruh Persepsi Mengenai Komitmen dan Budaya Organisasi Terhadap Persepsi Mengenai Kinerja Pegawai Pajak Di Direktorat Pemerikasaan, Penyidikan dan Penagihan Pajak Direktorat Jenderal Pajak, Tesis, Universitas Indonesia

Ulida L. Toruan 2004, Hubungan Antara Kompetensi dan Motivasi Terhadap Kinerja Pejabat Struktural di Badan Kepegawaian Negara, Tesis, Universitas Indonesia, Jakarta 